\title{
LAVA TUBE REMELT BY RADIANT HEAT AND BURNING GASSES
}

\author{
Kevin Allred *
}

\section{ABSTRACT}

Some volcanologists assume that interior surfaces of hot lava tubes can commonly be remelted by burning gases and radiant heat. Pending further data, this appears to be unlikely.

Keywords: lava tubes, speleogenesis, radiant heat
\end{abstract}

\section{INTRODUCTION}

Country rock can be eroded by flowing lava. It occurs by partial melting accompanied by mechanical plucking of unmelted crystals (Cruikshank and Wood 1972, Coombs and others 1990, Allred and Allred 1997) and has been defined as "thermal erosion". The necessity of melting as a component of thermal erosion is particularly obvious with the recent recognition of the effect on buried lava tubes that are intersected by active flows. These older extraneous tubes had an air-cooled resistance to thermal erosion and caused the newer flow to divert around them, leaving a separating rind (Allred and Allred 1997a, Allred and Allred 1997b). There is also some evidence of convective gaseous turbulence melting country rock around the perimeters of lavafall plunge pools (Allred and Allred, 1997b). This paper primarily deals with the feasibility of burning gases and radiant heat in melting the interior surfaces of lava tubes.

\section{DISCUSSION}

The subject of remelt must begin with T.A. Jaggar, a pioneer in volcanology of Hawaii in the early 1900's. At Kilauea caldera, he undertook ingenious methods to study the little understood phenomena of volcanic eruption. An interesting feature observed above the crusted over, active lava lakes of the Caldera were hollow spatter or driblet cones (Jaggar 1917a, 1917b). When the surface of the lakes subsided, convection apparently caused a super-heated mixture of gas and air to blast up through these cones which he then called "blowing cones". These could have banners of flame above them and become "natural blow-pipes of burning sulfur and hydrogen"(1917a). The greatest heat occurred in the intense turbulence at the orifice itself. Jaggar estimated temperatures of at least $1130^{\circ} \mathrm{C}$ using seger cones. Based on relative glows and steel pipe oxidized to a dripping incandescence after being held only nine minutes in one flaming orifice, he estimated the burning flames reached $1350^{\circ} \mathrm{C}$. These highest temperatures are far above the liquidus temperature of lava. An alternative explanation is

* P.O. Box 376, Haines, Alaska 99827. 
that in the turbulence of super-heated air, an oxidation reaction occurred, making the steel melt at lower temperatures than what Jaggar supposed. Oxidation from commonly used oxygen-acetylene cutting torches is triggered with pure oxygen at temperatures as low as $\sim 400^{\circ} \mathrm{C}$ (Oberg and Jones, 1972). In the blowing cones, oxygen concentrations would be less than that of air $(20 \%)$, but in a turbulent, super-heated condition. Regardless of the cause or actual temperatures, the basalt of the blowing cones did melt away.

When Jaggar observed vermiform (tubular lava) stalactites in lava tubes, he concluded they also were products of remelt from burning gasses, even after the lava had ceased to flow in the tubes (Jaggar 1931, 1947). But, any source of the supposed gas is unexplained, and it is illogical for the thin delicate stalactites to survive a space occupied by a melting inferno of burning gasses. Despite obvious complications, this remelt view has been widely accepted (Hjelqvist 1932, Perret 1950, McClain 1974, Baird and others 1985). We have recently shown that these tubular lava stalactites are not remelt features at all, but segregations (differentiated residual liquid) extruded from partially crystallizing lava into the cooling lava tubes. The driving mechanism is thought to be the gas pressure of retrograde boiling (Allred and Allred, in press).

\section{Incandescence, Glaze and Pendants}

Sometimes lava remelt is inferred by the glow color of the lava tube walls (Macdonald, 1964). With the aid of an optical pyrometer, accuracy in readings depends on ones proximity to the tested lava (Swanson, 1973). Still more inaccuracy is incurred by trying to judge by sight alone under different lighting conditions. In incandescent steel, skilled observers may vary as much as $100^{\circ} \mathrm{F}\left(55^{\circ} \mathrm{C}\right)$ in their estimations of relatively low temperatures by color, and beyond $2200^{\circ} \mathrm{F}\left(1205^{\circ} \mathrm{C}\right)$ it is practically impossible to make estimations with any certainty (Oberg and Jones, 1972). Without an accurate measuring device, it would appear as difficult to estimate lava temperature as it is to describe the colors in charts designed to show us how (Oberg and Jones 1972, Beiser 1991). In one such chart (Fig. 1) the lava would be "yellow" to well below the crust-melt interface, the point at which cooling Kilauea lava can no longer flow.

Investigators have claimed that common lava tube glaze and tapered shark tooth stalactites are also evidence of remelt by burning gases and radiant heat (Jaggar 1931, Macdonald 1964, Peterson and Swanson 1974, Harter 1971,1978,1993). Lava glaze is defined as "a thin, smooth, vitreous surface" (Larson, 1993). This definition is somewhat misleading, as glassy surfaces don't

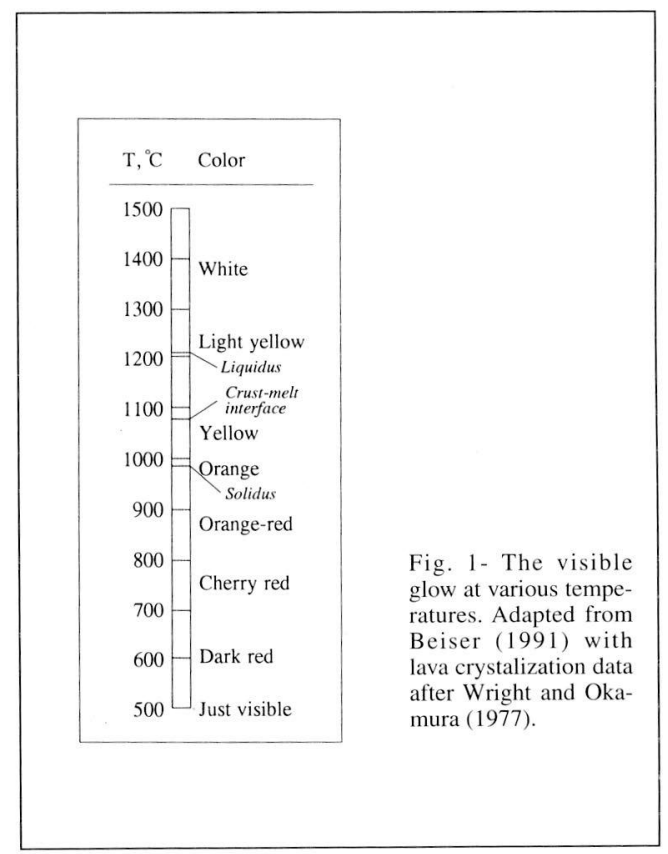



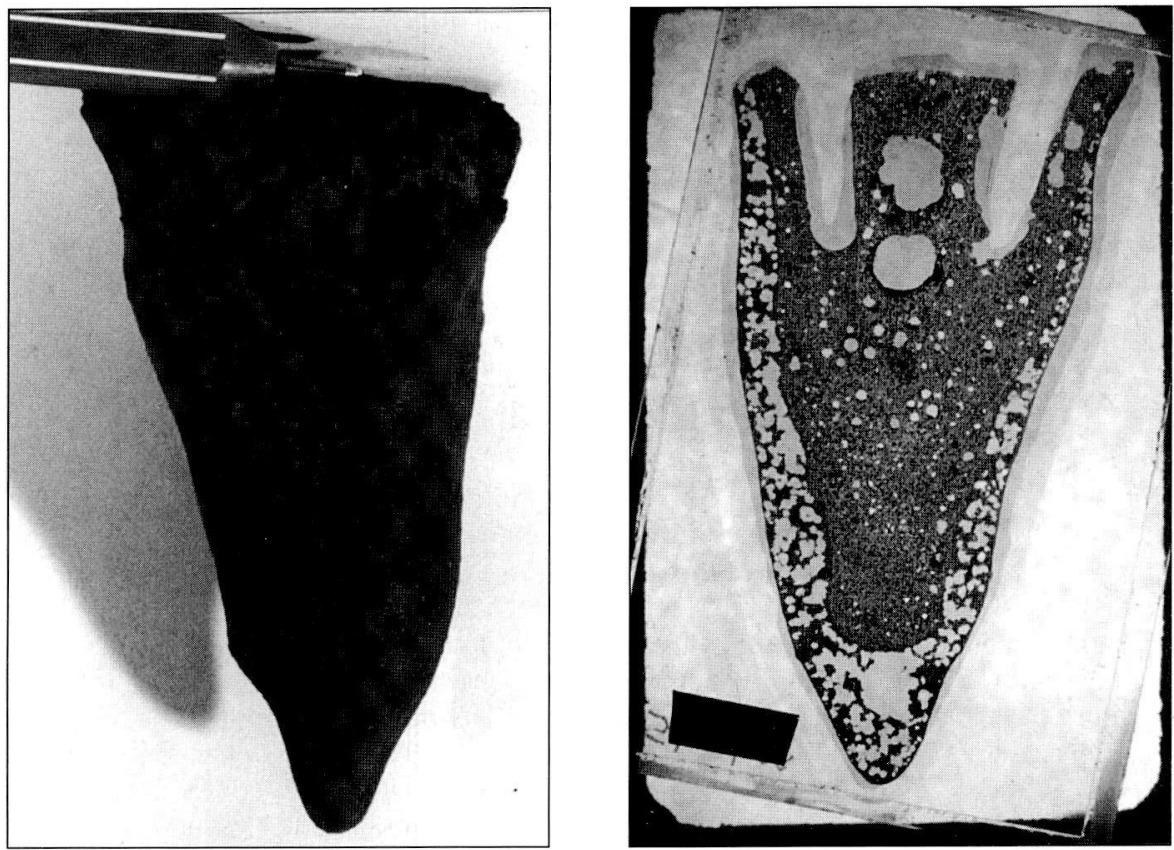

Fig. 2- Shark tooth stalactite and its thin section. Photos by Margaret Palmer.

occur in slowly cooling lava tubes. Here, glaze is defined as the silver luster (sometimes oxidized to reddish or brown) commonly covering the interior surfaces of lava tubes. It is not more than about $50 \mathrm{~mm}$ thick, and its characteristic luster comes from light reflecting off of facets of tiny magnetite octahedrons. Magnetite crystallizes at temperatures below the crust-melt interface between $1030^{\circ} \mathrm{C}$ and $980^{\circ} \mathrm{C}$ (Wright and Okamura, 1977). Therefore, it is not proof of remelt.

Tapered pendants are commonly called shark tooth, or teat stalactites (Larson, 1993). They are often found in areas susceptible to splattering, or fluctuating lava levels. Many of these stalactites can be quite vesicular, and have a remarkable resemblance to the foamy peaks of the beaten egg-white of meringue.

A thin section was made of a shark tooth stalactite (Fig. 2). It had eight distinct layers or accreted linings ranging from $5 \mu \mathrm{m}$ to $2.5 \mathrm{~cm}$ thick (Allred and Allred in press). All of these were visible only with at least 100 power of a microscope. Such linings also commonly coat the ceiling between pendants. The magnetite glaze between these linings is continuous to discontinuous. It is unclear if the glaze along the transitions crystallized before each subsequent coating, or sometime later in the cooling process. However, it is safe to conclude that pendants are products of accreted lava and not remelt. If a pendant is only partially exposed between submerge cycles, it can become bulbous or teatshaped. Transitional distinctions between linings will then end at the point of non-emergence or non-submergence. Tubular lava stalactites can sometimes grow out of pendants in favored conditions as in other linings (Allred and Allred, in press).

Using paraffin, my wife and I attempted to simulate stalactite formation according to the popular "remelt" hypothesis. Earlier we had successfully created tubular paraffin stalactites similar to those of lava (Allred and Allred, unpub.). But in this instance, we 
repeatedly flash heated a horizontal, flat, paraffin "ceiling". This only produced driblet projections less than three millimeters long. Any larger projections were quickly, and preferentially melted away when exposed to the heat. If the "ceiling" was inclined, not even the tiny driblets could be formed. After experimenting with this, we became even more convinced that these pendants must be products of accretion.

\section{Radiant Heat}

All objects have the property of absorbing as much radiation (electromagnetic waves) as they can emit. A theoretical black body has a surface texture which allows it to be a perfect emitter and absorber with an emissivity of 1 . Matte black paint is .97 on the scale (Beiser, 1991). If it is assumed that lava or basalt are $~ .9$ emissivity, they are somewhat limited in their emissive and absorption capabilities. Yet, even though the transfer of heat is slower, the ceiling would eventually take on the temperature of the flowing lava, were it not for three things: First, conduction might sometimes exceed the radiant heat. Second, the conductive surface area of the arched ceiling and walls is larger than the radiating surface of flowing lava. Third, I propose that gas between the flowing lava and the walls and ceiling acts as a screen and the absorbing molecules reflect a portion of the radiation back towards the source. The thinner atmosphere of our earth functions in a similar way (Beiser, 1991). If there is a morphological change to the tube such as a new skylight to cause significant temperature differences, convective currents begin, and heated gas particles are dispersed to the cooler parts in the tube. When the temperatures are nearly the same in an area, the friction of the gas particles slows down or stops convection. The screen becomes more effective, and heat is conserved in the lava stream rather than causing a meltdown of the ceiling. Thus, as long as there is space between the two surfaces, the radiation reaching the slightly conductive ceiling will be less than the emission of the lava below. This can be illustrated by holding ones' hand near a very hot object, but not being able to safely touch it.

When convective currents are caused by mechanical means (lavafalls, or turbulent rapids) the balance may be upset, and heated gas can be blown against a surface where it otherwise would not. Over time, this heat flow may exceed the rock's conduction, specific heat, and enthalpy of fusion. Melting of the surface will occur as suggested by Allred and Allred (1997b). The shape of walls around the perimeters of plunge pools in lava tubes have the appearance of rounded forms of country rock under a very thin, or nonexistent lining, rather than unmelted broken surfaces. Some walls resemble ablation scallops commonly seen in glacier caves. Glaze covering these surfaces is identical to the surfaces elsewhere.

\section{Do Burning Gasses Contribute to Remelt?}

So, is it possible to use the present data collected from volcanologists to accurately predict if remelt can occur from burning gasses and radiant heat acting without convection? Not conclusively. There are still too many unknown values that must be supposed in order for any exact determination. For instance, how much atmospheric air is being drawn into cracks and skylights before expanding and being balanced with the gases? How much gas escapes through cracks? How much of the gases which can oxidize are present? Does higher heat allow lower concentrations of these gases to burn than at room temperature? Does the lighter hydrogen separate from gases, collect along the 
ceiling and "flow" to be burned where oxygen is available? What is the remelt temperature of basalt that has lost part of its water content, and do we Fig. a remelt starting from solidus or somewhere close to the crust-melt interface? Does radiant emissivity change during cooling textural changes?

Despite the obvious lack of data, below is a model of the theoretical possibility of remelt from burning gases in a lava tube. The chosen conditions greatly favor a remelt scenario. A theoretical lava tube is considered in two sections reflecting the recognized differences in loss of gas bubbles (Swanson 1973, Cashman and others 1994). For more simplicity, the negligible cooling of lava through the tube system was not considered, but is listed in the values below. The reader should understand the concept that the ceiling and wall linings accreted in the first place because the conduction of the ceiling rock exceeded the melting ability of the flowing lava against them.

In the model, all three common gases which oxidize $\left(\mathrm{H}_{2}, \mathrm{CO}, \mathrm{H}_{2} \mathrm{~S}\right)$ are drawn through a significant portion of a lava tube, then finally burn in one small area. The possibility of such complete oxidation is inferred by Greenland (1987a, pg. 762). However, considering the multitude of analyses showing low concentrations of these gases (Greenland, 1987a, 1987b), and their nearly consistent presence, in reality they usually remain diffused and mostly unburned. Not included here are trivial amounts of hydrogen liberated in oxidation of magnetite $\left(\mathrm{Fe}_{3} \mathrm{O}_{4}\right)$ to hematite $\left(\mathrm{Fe}_{2} \mathrm{O}_{3}\right)$ during advanced cooling. Gas exsolution has been found to be $<5 \%$ volume in $11 \mathrm{~km}$ (Cashman and others, 1994), and is not included in the gas liberation value, "V" in the list below.

The sulfur concentrations are low in Kilauea and Mauna Loa basalt, averaging 153ppm (Franczyk and others, 1987). Of the portion carried away in gases, most of the loss is within $2 \mathrm{~km}$ of the vent. This follows the trend of overall gas loss. I observed elemental sulfur deposits around cracks atop the roofs of recently cooled lava tubes near Kupaianaha, Kilauea Volcano. This indicates that at least a portion did not oxidize, but condensed upon cooling. Sulfur is not considered here as a significant source of heat in lava tubes.

Basalt which has crystallized at virtual atmospheric pressure will require hotter temperatures to reverse the process and be melted at atmospheric pressure. This is because some water has been lost by exsolution, and without it the melting temperature is higher. Water cannot be forced back into the lava solution without pressure; its solubility at atmospheric pressure is zero (Charmichael and others, 1974). Greeley (1987) reported some minerals of a dacite block from the preflow terrain had been melted and flowed out through a wall collapse into a Mt. St. Helens lava tube. A sample of this dacite was heated gradually, and only showed signs of melting above $1200^{\circ} \mathrm{C}$. It is not clear that these melted residuals were indeed from the preflow terrain, as they could also have been segregation drainage from the linings (Allred and Allred in press). At any rate, the high temperatures of this remelt experiment seems to confirm the higher temperatures required to melt a water deficient basalt (Carmichael and others, 1974, pg.8). In this paper I have chosen a rather modest $1100^{\circ} \mathrm{C}$ (Baird and others, 1985) as a flow temperature for remelt, even though it is only slightly above the crust-melt interface of primary basalt (Wright and Okamura, 1977). In this model, convection distributes radiant heat above the lava, balancing the ceiling temperature at $1070^{\circ} \mathrm{C}$.

\section{Useful Values}

$\Delta \mathrm{Hch}$ heat of combustion of hydrogen $\left(2 \mathrm{H}_{2}+\mathrm{O}_{2} \Rightarrow 2 \mathrm{H}_{2} \mathrm{O}\right.$ gas $)$ to $\mathrm{H}_{2} \mathrm{O}$ gas at $1070^{\circ} \mathrm{C}$ : Begin with $-241.8 \mathrm{~kJ} / \mathrm{mol}$ at $25^{\circ} \mathrm{C}$ at constant pressure (Brown and others, 1991). At $1070^{\circ} \mathrm{C}$, the volume of the gas is increased from heat expan- 
sion. Using Charles's Law, a mole $(22.414 \mathrm{~L})$ at $0^{\circ} \mathrm{C}$ will take up a predictably larger volume at $1070^{\circ} \mathrm{C}$. In this equation, $\mathrm{V}$ is the volume and $\mathrm{T}$ is the temperature in Kelvins. The minus value means that the reaction is exothermic:

$\frac{V_{1}}{T 1{ }^{\circ} \mathrm{K}}=\frac{V_{2}}{T 2{ }^{\circ} \mathrm{K}}=-241.8 \mathrm{KJ} / 110.199 \mathrm{~L}$ at $1070^{\circ} \mathrm{C}$

$\Delta \mathrm{Hcco}$ heat of combustion of carbon monoxide $\left(2 \mathrm{CO}+\mathrm{O}_{2} \Rightarrow 2 \mathrm{CO}_{2}\right)$ as in the equation above:

$-283 \mathrm{~kJ} / 110.199 \mathrm{~L}$ at $1070^{\circ} \mathrm{C}$

$\Delta \mathrm{Hchs}$ heat of combustion of hydrogen sulfide $\left(2 \mathrm{H}_{2} \mathrm{~S}+3 \mathrm{O}_{2} \Rightarrow 2 \mathrm{SO}_{2}+2 \mathrm{H}_{2} \mathrm{O}\right.$ gas $)$ as in the equation above: $-518.53 \mathrm{~kJ} / 110.199 \mathrm{~L}$ at $1070^{\circ} \mathrm{C}$.

$\mathrm{H} \quad$ total lava heat lost from a $12 \mathrm{~km}$ lava tube: $2900 \mathrm{~J} / 100 \mathrm{~g}(\mathrm{Helz}, 1993)=6.931$ $\mathrm{cal} / \mathrm{g}$.

$\mathrm{Hc} \quad$ total cal. lost from lava per meter ${ }^{3}$ in $12 \mathrm{~km}$ based on a density of $2.7 \mathrm{~g} / \mathrm{cm}^{3}$ : $\mathrm{Hc}=6.931 \mathrm{cal} / \mathrm{g} \mathrm{x}\left(2.7 \times 10^{6} \mathrm{~g} / \mathrm{m}^{3}\right)=18,713,700 \mathrm{cal} / \mathrm{m}^{3}$.

T1 crust $/$ melt interface at $1070^{\circ} \mathrm{C}$. Volume of crystals: $59 \%$ (Wright and Okamura, 1977, Fig. 16).

T2 lava begins to flow at $1100^{\circ} \mathrm{C}$ (Baird and others, 1985, pg.159). Volume of crystals: $38 \%$ (Wright and Okamura, 1977, Fig. 16).

$\Delta \mathrm{T} 3 \quad\left(\mathrm{~T} 2^{\circ}-\mathrm{T} 1^{\circ}\right)$.

$\Delta \mathrm{T} 4 \quad$ change in temperature in $12 \mathrm{~km}: 7^{\circ} \mathrm{C}(\mathrm{Helz}, 1993)$.

c heat capacity of basalt: $.3 \mathrm{cal} / \mathrm{g} /{ }^{\circ} \mathrm{C} / \mathrm{s}$ (Jaeger, 1968).

$\Delta \mathrm{C} \quad$ change in crystal content in $\Delta \mathrm{T} 4$ during flow of an $12 \mathrm{~km}$ tube: $5.6 \%$ (Helz, 1993).

$\mathrm{K}$ thermal conductivity of basalt: From $.0052 \mathrm{~cm}^{2} / \mathrm{s} / \mathrm{cm}\left(\mathrm{cm}^{2} /{ }^{\circ} \mathrm{C}\right)$ (Weast and others, 1958) for a $3.09 \mathrm{~g} / \mathrm{cm}^{3}$ basalt adjust for the density of $\rho 1=.0032 \mathrm{~cm}^{2} / \mathrm{s} / \mathrm{cm}$ $\left(\mathrm{cm}^{2} /{ }^{\circ} \mathrm{C}\right)$.

$\varepsilon$

enthalpy of fusion of basalt: $80 \mathrm{cal} / \mathrm{g}$. (Jaeger, 1968)).

$\rho \quad$ grain density of average basalt: $3.09 \mathrm{~g} / \mathrm{cm}^{3}$ (Daly, 1944).

po fluid density of lava with 5\% crystals: $\rho-13 \%$ for expansion from total crystalline state (Daly, 1944), $-5 \%$ of $13 \%$ to account for $5 \%$ crystals in erupting lava $\left(\right.$ Cashman and others, 1994) $=2.71 \mathrm{~g} / \mathrm{cm}^{3}$.

p1 ceiling lining bulk density: $1.9 \mathrm{~g} / \mathrm{cm}^{3}$ (Allred and Allred, 1997b, average of 10 lining samples).

Fr flow rate: $1.73 \mathrm{~m}^{3} / \mathrm{s}$ (Cashman and others, 1994, pg. 59). 
D average stream depth (50-75cm): 62cm (Cashman and others, 1994, p.59).

f velocity of lava stream (1-2m/s): $1.5 \mathrm{~m} / \mathrm{s}$ (Hon and others, 1994).

$\mathrm{V}$ total gases liberated throughout an $11 \mathrm{~km}$ tube $/ \mathrm{sec}$. $53 \mathrm{Fr}$ (Cashman and others, 1994, pp. 59).

v1 gas loss in the first two $\mathrm{km}$ of $11 \mathrm{~km}$ of tube/sec: .25 Fr (Cashman and others, 1994, Fig.8).

v2

gas loss in last nine $\mathrm{km}$ of $11 \mathrm{~km}$ of tube/sec: .28 Fr (Cashman and others, 1994, Fig.8).

$\mathrm{H}_{2}$ percentage in gas: $.48 \mathrm{~mol} \%$ of average of full gas analyses Greenland (1987a), Table 28.1 from Kilauea 1918-1919 and Greenland (1987b), Table 30.1 from Mauna Loa).

\section{Remelt in the First Two Kilometers of an Active Lava Tube}

1. $\xi=$ volume of combustible gases available $/ \mathrm{s} / \mathrm{km}$ : A total of $.25 \mathrm{Fr}$ of the gas lost into the tube system are within $2 \mathrm{~km}$ from the vent. An average $.0048, .0021, .0085$ of the liberated gas content is $\mathrm{H}_{2}, \mathrm{CO}$, and $\mathrm{H}_{2} \mathrm{~S}$ respectably:

$$
\begin{aligned}
& H_{2} \xi=\mathrm{v} 3\left(\frac{\mathrm{v} l}{2}\right)=.0010 \mathrm{~m}^{3} / \mathrm{s} / \mathrm{km} \\
& \mathrm{CO} \xi=\mathrm{v} 4\left(\frac{\mathrm{v} l}{2}\right)=.00045 \mathrm{~m}^{3} / \mathrm{s} / \mathrm{km} \\
& \mathrm{H}_{2} \mathrm{~S} \xi=\mathrm{v} 5\left(\frac{\mathrm{v} l}{2}\right)=.0018 \mathrm{~m}^{3} / \mathrm{s} / \mathrm{km}
\end{aligned}
$$

2. $\mathrm{Hb}=$ Heat budget: Calories of burning $\mathrm{H}_{2}, \mathrm{CO}$, and $\mathrm{H}_{2} \mathrm{~S}$ versus calories drawn away by conduction per second into the ceiling. A hypothetical skylight one $\mathrm{km}$ upstream allows all released burnable gases of that $\mathrm{km}$ to ignite in an area $10 \mathrm{~m}^{2}$ near the skylight where oxygen is available. Heat of combustion for $\Delta \mathrm{Hch}(524400.860$ $\left.\mathrm{cal} / \mathrm{m}^{3}\right), \Delta \operatorname{Hcco}\left(613752.865 \mathrm{cal} / \mathrm{m}^{3}\right)$, and $\Delta \operatorname{Hchs}\left(1124555.738 \mathrm{cal} / \mathrm{m}^{3}\right)$ multiplied by their respective volume/s $(\xi)$ equals heat given off below the affected area. Fig. that only $2 / 3$ of the heat radiates upwards to the arched ceiling. Subtract the amount being conducted into the one meter thick roof of the affected area, figuring the difference between the crust-melt interface and the $20^{\circ} \mathrm{C}$ surface temperature to get the heat budget $(\mathrm{Hb})$ : 


$$
\begin{gathered}
H b=.666\left[\left(\mathrm{H}_{2} \xi \times \Delta H c h\right)+(C O \xi \times \Delta H c c o)+\left(H_{2} S \xi \times \Delta H c h s\right)\right] \\
-\frac{K\left[10^{5} \mathrm{~cm}^{2}(T 1-20)\right]}{100 \mathrm{~cm}}=-1478.692 \mathrm{cal} / \mathrm{s}
\end{gathered}
$$

The conduction into the ceiling exceeds the amount of heat given off from the burning gases.

3. Since conduction decreases as the roof is thickened, we can calculate the minimum roof thickness at which remelt begins:

$$
\frac{K\left[10^{5} \mathrm{~cm}^{2}(\mathrm{Tl}-20)\right]}{.666\left[\left(\mathrm{H}_{2} \xi \times \Delta H c h\right)+(\mathrm{CO} \xi \times \Delta H c c o)+\left(\mathrm{H}_{2} \mathrm{~S} \xi \times \Delta H c h s\right)\right]}=1.78 \text { meters }
$$

Had the heat from burning gases been more than the conduction into the one meterthick roof, we could have calculated the rate of remelt:

4. $\varepsilon 1=$ Enthalpy of fusion of affected area: Fig. there are $10^{5} \mathrm{~cm}^{2}$ (for an area $10 \mathrm{~m}^{2}$ spanning the ceiling near an entrance). We are attempting to melt rock having a density of $\rho 1,1 \mathrm{~mm}$ into the surface, multiplied by the enthalpy of fusion. Next, since the melting temperature of basaltic minerals covers a range of $980-1205^{\circ} \mathrm{C}$, and we are only talking about the range from the crust-melt interface to $1100^{\circ} \mathrm{C}$, we will adjust for this. Since 21 volume $\%$ crystals are all that need to be melted for the rock to begin flowing:

$$
\varepsilon 1=.21 \varepsilon\left[\frac{1.9}{10}\left(10^{5} \mathrm{~cm}^{2}\right)\right]=319,200 \text { calories }
$$

5. $\mathrm{cl}=$ heat capacity of affected area: Multiply the grams of rock to be melted by the heat capacity value, and then multiply the temperature change from $1070-1100^{\circ} \mathrm{C}$ :

$$
c 1=\left(1.9 \times 10^{4} \mathrm{~g} \times \mathrm{c}\right) \Delta T 3=1.71 \times 10^{5} \text { calories }
$$

6. $\mathrm{t}=$ time to melt $1 \mathrm{~mm}$ deep of rock in the affected area:

$$
t=\frac{\varepsilon l+c l}{H b}
$$

\section{Remelt in an Actively Flowing Tube in the Lower Nine Kilometers}

7. $\xi=$ Combustible gas available s/km: $.28 \mathrm{Fr}$ of liberated gas was lost in the last 9 $\mathrm{km}$ of the tube. As in equation 1, only a portion of this gas is combustible:

$$
\begin{aligned}
& H^{2 \xi}=v 3\left(\frac{\mathrm{v} 2}{9}\right)=.00025 \mathrm{~m}^{3} / \mathrm{s} / \mathrm{km} \\
& C O \xi=v 4\left(\frac{\mathrm{v} 2}{9}\right)=.00011 \mathrm{~m}^{3} / \mathrm{s} / \mathrm{km} \\
& H^{2} S \xi=v 5\left(\frac{\mathrm{v} 2}{9}\right)=.00045 \mathrm{~m}^{3} / \mathrm{s} / \mathrm{km}
\end{aligned}
$$


8. $\mathrm{Hb}=$ Heat budget of burning $\mathrm{H}_{2}, \mathrm{CO}$, and $\mathrm{H}_{2} \mathrm{~S}$ versus conduction under conditions as in equation 2:

$$
\begin{gathered}
H b=.666\left[\left(H_{2} \xi \times \Delta H c h\right)+(C O \xi \times \Delta H c c o)+\left(H_{2} S \xi \times \Delta H c h s\right)\right] \\
-\frac{K\left[10^{5} \mathrm{~cm}^{2}(T l-20)\right]}{100 \mathrm{~cm}}=-2890.696 \mathrm{cal} / \mathrm{s}
\end{gathered}
$$

The conductivity of heat into the ceiling is 7 times the heat production from all burning gases. Using equation 3 , the minimum roof thickness for remelt to begin is 7.1 meters.

\section{CONCLUSIONS}

In this modeling, remelt cannot occur from burning gases, unless the roof is at least $1.7 \mathrm{~m}$ thick and near the vent. Gas analyses from other locales usually show consistent and minor amounts of diffused $\mathrm{H}_{2}, \mathrm{CO}$, and $\mathrm{H}_{2} \mathrm{~S}$. Thus, complete oxidation of gases is unlikely, and partial oxidation may occur through many areas of a lava tube or after exiting. It was assumed convection distributed radiant heat to the ceiling and kept it at $1070^{\circ} \mathrm{C}$. Similarly, even if burning could occur, the resulting heat would tend to be distributed by convection to adjacent cooler areas because of the temperature gradient. After lava flows about $12 \mathrm{~km}$ through a lava tube, estimated total heat $l o s t / \mathrm{m}^{3}(\mathrm{H})$ is approximately 13,000 times more than potential heat from all flammable gas liberated from that lava. Burning gases would be negligible in the overall heat budget.

Despite the improbability, remelt in lava tubes from burning gasses and radiant heat, is likely to continue to be controversial until more is learned of the thermodynamics. A means should be found to accurately monitor the internal temperatures and gases of lava tubes away from the entrances. One way would be through drilling into the ceiling of an active tube. As pointed out by Jim Kauahikaua (pers. comm. 1996), it would be a potentially dangerous thing to do directly above the tube, since water would be used as a coolant. However, a tube could be pinpointed electromagnetically, then drilled diagonally to offer protection from potential collapse of the roof.

\section{ACKNOWLEDGEMENTS}

I wish to thank Mark Fontenot, who helped significantly on the calculations. My wife, Carlene, set up the paraffin experiment.

\section{REFERENCES}

ALLRED, K., and C. ALLRED. 1997a. The December 1996 Allred Hawaii Expedition. Newsletter of the Hawaii Speleological Survey, July 1997, No.2, pp.3-7.

ALLRED, K. AND C. ALLRED. 1997b. Development and Morphology of Kazumura Cave, Hawaii. Journal of Cave and Karst Studies, Vol.59, No.2, pp.67-80.

ALLRED, K. AND C. ALLRED. in press, 1997. Tubular lava stalactites and other related segregations. Journal of Cave and Karst Studies.

BAIRD, A.K., D.C. MOHRIG and E.E. WELDAY. 1985. Vapor deposition in basaltic stalactite, Kilauea, Hawaii. Lithos, 18, pp.151-160. 
BEISER, A.. 1991. Physics, fifth edition. Addison-Wesley Publishing Company, Mass. 930pp.

BROWN, T.L., H.E. LEMAY JR. and B.E. BURSTEN. 1991. Chemistry the Central Science, fifth edition. Prentice Hall, NJ, 1045pp.

CARMICHAEL, I.S.E., F.J. TURNER and J. VERHOOGEN. 1974. Igneous Petrology. McGraw Hill, New York, 739pp.

CASHMAN, K.V., M.T. MANGAN and S. NEWMAN. 1994. Surface degassing and modifications to vesicle size distributions in active basalt flows. Journal of Volcanology and Geothermal Research 61, pp.58,60.

COOMBS, C.R., B.R. HAWKE and L. WILSON. 1990. Terrestrial Analogs to Lunar Sinuous Rilles: Kauhako Crater and Channel, Kalaupapa, Molokai, and Other Hawaiian Lava Conduit Systems. Proceedings of the 20th Lunar and Planetary Science Conference, Lunar and Planetary Institute, Houston. pp. 195-206.

CRUIKSHANK, D.P. and C.A. WOOD. 1972. Lunar Rilles and Hawaiian Features: Possible Analogues. The Moon, 3, pp.412-447.

DALY, R.A., 1944. Volcanism and petrogenesis as illustrated in the Hawaiian Islands. Bulletin of the Geological Society of America, vol.55, pp.1363-1400.

FRANCZYK, K.J., E.K. GIBSON, and R.I. TILLING. 1987. Sulfur and carbon abundances in Hawaiian tholeiite lavas: 1972-1975 eruptions of Kilauea and 1975 eruption of Mauna Loa. U.S. Geological Survey Professional Paper 1350. pp.791-803.

GREELEY, R., The role of lava tubes in Hawaiian volcanoes. U.S. Geological Survey Professional Paper 1350, pp.1589-1602.

GREENLAND, L.P. 1987a. Hawaiian Eruptive Gases. U.S. Geological Survey Professional Paper 1350, pp 759-770.

GREENLAND, L.P. 1987b. Composition of gases from the 1984 Eruption of Mauna Loa Volcano. U.S. Geological Survey Professional Paper 1350, pp.781-790.

HARTER, R. 1971. Lava Stalagmites in Government Cave. Plateau, a quarterly of the Museum of Northern Arizona vol.4, no.1, pp.14-17

HARTER, R.G. 1978. Strata of Lava Tube Roofs. NSS Bulletin 40, pp.118-122

HARTER, R. 1993. Lava stalactites: terminology, shape and possible origins. Proceedings of the Third International Symposium on Vulcanospeleology, pp.111-112.

HELZ, R.T. and C. HELIKER. 1993. Thermal efficiency of lava tubes at Kilauea Volcano, Hawaii. (abstract) IAVCEI General Assembly, Canberra, pg.47.

HJELMQVIST, S. 1932. Uber Lavastalaktiten aus einer Lavhohle auf Sud-Island. Kungl. Fysiografiska Sallskapets I Lund Forhandlingar, BD2. Nr. 2. pp.6-13. (in German)

HON, K., J. KAUAHIKAUA, R. DENLINGER AND K. MACKAY. 1994. Emplacement and inflation of pahoehoe sheet flows: Observations and measurements of active lava flows on Kilauea Volcano, Hawaii. Geological Society of America Bulletin, vol.106, pp.351-370.

JAEGER, J.C. 1968. Cooling and solidification of Igneous Rocks. pp. 503-536, Basalts, vol.2. by H.H. Hess and Arie Poldervaart. Interscience Publishers, New York, 862pp.

JAGGAR, T.A. 1917a. Thermal gradient of Kilauea Lava Lake. Journal of the Washington Academy of Science, vol. VII, no. 13, pp.397-405.

JAGGAR, T.A. 1917b. Volcanologic Investigations at Kilauea. vol.44, pp. 200-216.

JAGGAR, T.A. 1931. Lava Stalactites, Stalagmites, Toes, and "Squeeze-ups". The Volcano Letter, No. 345, pp.1-3. JAGGAR, T.A. 1947. Origin and development of craters. Waverly Press Inc., Baltimore, MD.

KAUAHIKAUA, J. 1996. personal communication, U.S. Geological Survey Hawaiian Volcano Observatory. LARSON, C.V. 1993. An Illustrated Glossary of Lava Tube Features. Western Speleological Survey Bulletin 87. MACDONALD, G.A. 1964. Hawaiian Volcanoes during 1955. U.S. Geological Survey Bulletin 1171, 170pp. MCCLAIN, D.W. 1974. Geology of Lavacicle Cave Geological Area. a thesis for the University of Oregon. OBERG, E. and F.D JONES. 1972. Machinery's Handbook. Industrial Press, New York, 2420pp.

PERRET, F.A. 1950. Volcanological Observations. Publication 549, Carnegie Institution of Washington, pp.74-77.

PETERSON, D.W. and D.A. SWANSON. 1974. Observed Formation of Lava Tubes During 1970-71 at Kilauea Volcano, Hawaii. Studies in Speleology, Vol.2, Part 6.

SWANSON, D.A. 1973. Pahoehoe Flows from the 1969-1971 Mauna Ulu Eruption, Kilauea Volcano, Hawaii. Geological Society of America Bulletin, v.84, pp.615-626, 13 Figs

WEAST, R.C., M.J. ASTTE and W.H. BEYER. 1958. Handbook of Chemistry and Physics, Fortieth Edition. Chemical Rubber Company, Cleveland Ohio, 3456 pp.

WRIGHT, T.L. and R.T.OKAMURA. 1977. Cooling and Crystallization of Tholeiitic Basalt, 1965 Makaopuhi Lava Lake, Hawaii. U.S. Geological Survey Professional Paper 1004, 78 pp. 